\title{
Revision of the spider genera Ariston O. P.-Cambridge, 1896 and Siratoba Opell, 1979 (Arachnida: Araneae: Uloboridae) with description of two new species
}

\author{
Lidianne Salvatierra ${ }^{1,2^{*}}$, Ana Lúcia Tourinho ${ }^{1,3}$ and Antonio D Brescovit ${ }^{4}$
}

\begin{abstract}
Background: Ariston O. P.-Cambridge, 1896 and Siratoba Opell, 1979 are two poorly known genera of the spider family Uloboridae, which together comprise six nominal species previously described. This study provides an update of the taxonomic status for both genera and the description of two new species for Ariston.

Results: The male of Ariston albicans O. P.-Cambridge, 1896 is described and illustrated for the first time, based on specimens from Chiapas, Mexico; Ariston reticens Gertsch \& Davis, 1942 is transferred to Siratoba, and Siratoba sira Opell, 1979 is considered its junior synonym; Ariston spartanus n. sp. is described based on male and female collected in Caicubi, state of Roraima, Brazil; and Ariston aglasices n. sp. is described based on a female collected in Bonampak, Chiapas, Mexico.

Conclusions: An emended diagnosis for Ariston and Siratoba and for each previously known species is provided. In total, five species are recognized in Ariston, including two new species, and two species are recognized in Siratoba.
\end{abstract}

Keywords: New World; Mexico; Brazil; Taxonomy; New species; Deinopoidea

\section{Background}

Ariston O. P.-Cambridge, 1896 and Siratoba Opell, 1979 are two poorly known genera of spiders of Uloboridae. Species from both genera can be diagnosed based on their small size, with females' length being less than $2.5 \mathrm{~mm}$, and a posterior epigynal hood (Opell 1979), which lead to the hypothesis they are closely related. This hypothesis was supported by Coddington (1990) as both genera share the radix as an embolic guide, a flat embolus, and the absence of a stridulatory apparatus.

The genus Ariston was described by O. P.-Cambridge (1896) based on an adult female type species A. albicans O. P.-Cambridge, 1896, from Tabasco, Mexico. Kraus (1955) extended the distribution of this species for

\footnotetext{
* Correspondence: lidiannetrigueiro@gmail.com

${ }^{1}$ Coordenação de Biodiversidade, Instituto Nacional de Pesquisas da Amazônia (INPA), Avenida André Araújo, 2936, Aleixo, Cx. Postal 478, Manaus, AM 69011-970, Brasil

${ }^{2}$ Department of Biological Sciences, The George Washington University,

Washington D.C. 20052, USA

Full list of author information is available at the end of the article
}

Honduras (Islas de la Bahía). In 1942, Gertsch and Davis described one more species, Ariston reticens, based on an adult male from San Luis Potosi, Mexico. The later species was placed in Ariston with some doubt, supported only by the difference on the interdistance of the eyes between this species and A. albicans. Opell (1979) revised $A$. albicans and described two new species, $A$. mazolus based on adult male from Colima, Mexico, and A. aristus, based on adult females from Barro Colorado Island, Panama. In this same paper, he erected the genus Siratoba to include the type species Ariston referens Muma and Gertsch, 1964 from Cochise, Arizona and S. sira from San Luis Potosi in Mexico.

In his revision, Opell (1979) was not able to provide a diagnosis based on the male and female genitalia characters for the genera because when he studied the species samples of both sexes for all species were not available. He provided then a diagnosis for Ariston and Siratoba based on the presence of a prominent epigynal hood, interdistance of the eyes, presence of an abdominal 


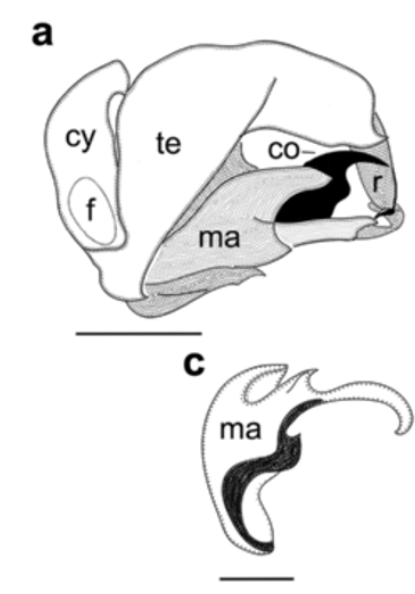

e

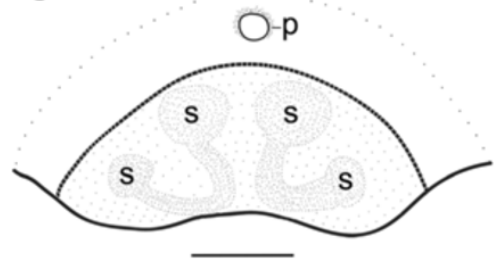

b

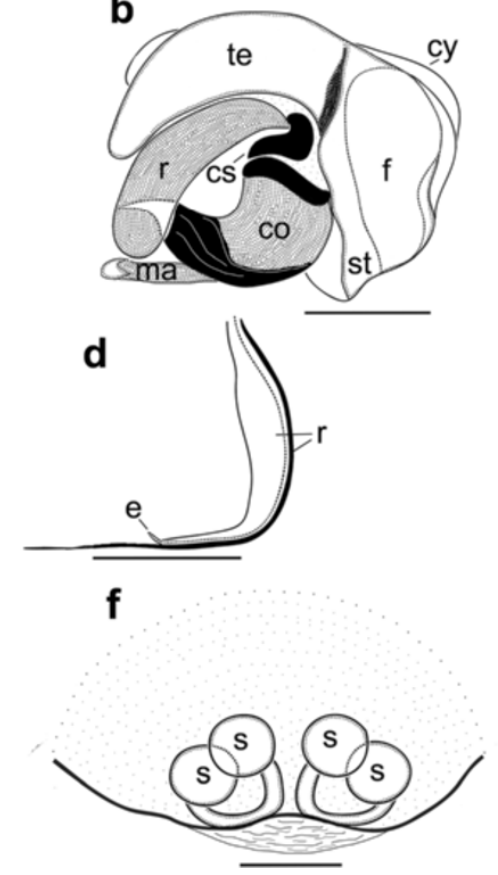

Figure 1 Ariston spartanus n. sp. (a) Male, palpus, retrolateral view; (b) prolateral view; (c) median aphophysis, ventrolateral view; (d) radix and embolus, anterior view. (e) Female, epigynum, ventral view; (f) cleared, dorsal view. Scale bars: (a,b,c,d) 0.1 mm, (e,f) 0.5 mm. co, conductor; cs, conductor spike; cy, cymbium; e, embolus; f, fundus; ma, median apophysis; p, epigynal pit; r, radix; s, spermathecae; st, subtegulum; te, tegulum.

middle peak, and the small body size of the species characteristic for both genera compared to other uloborids.

In this paper, we provide an emended diagnosis for each genus, and for all species included. For both, genera and species diagnosis, characters of the male palpus and epigynum as described by Opell (1979), and newly examined characters were used. We also described the male of A. albicans for the first time based on material from the type locality; two new species of Ariston are described, one based on male and female collected in the state of Roraima, Amazon basin, Brazil, and the other based on a female from Bonampak, Chiapas, Mexico; and
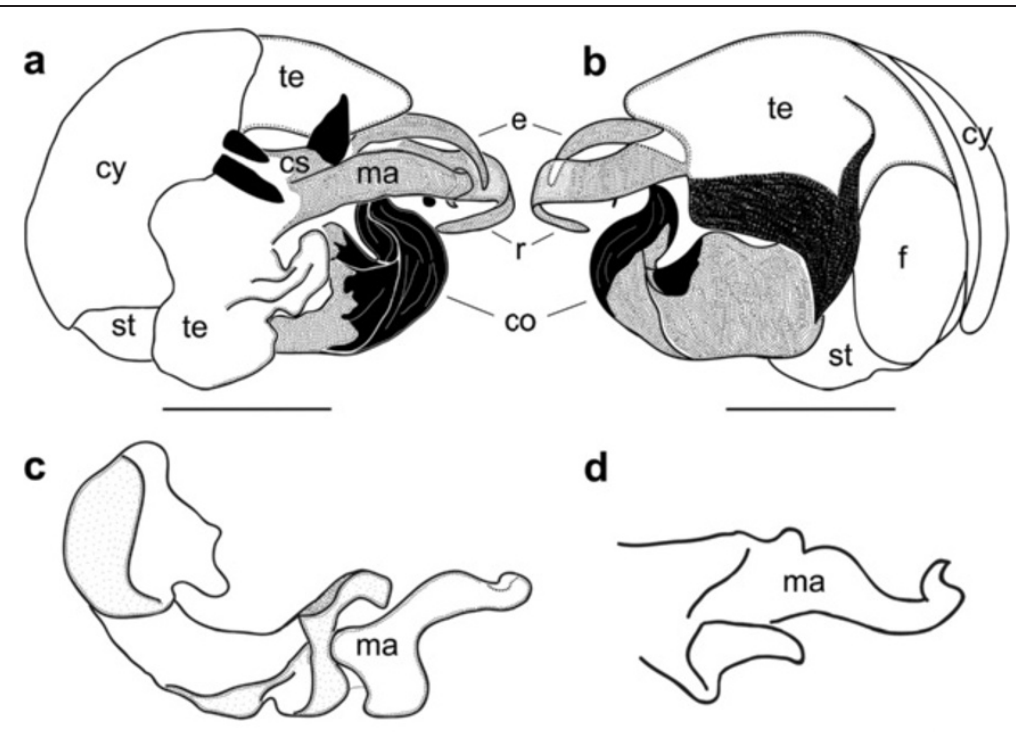

d

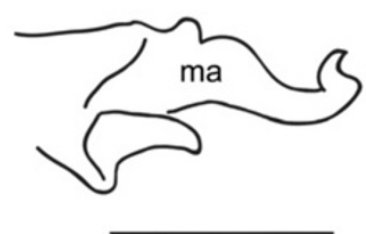

Figure 2 Ariston albicans O. P. Cambrigde, 1896, male, palpus. (a) Retrolateral view, (b) prolateral view, (c) median aphophysis, dorsolateral view, (d) same, prolateral view. Scale bars: (a,b,c,d) $0.5 \mathrm{~mm}$. co, conductor; cs, conductor spike; cy, cymbium; e, embolus; f, fundus; ma, median apophysis; r, radix; st, subtegulum; te, tegulum. 
finally, A. reticens Gertsch and Davis, 1942 is transferred to Siratoba based on the new diagnosis herein proposed for the genus.

\section{Methods}

The terminology for anatomical structures follows Opell (1979). Epigynes were cleared with clove oil. Palpi were cleared with methyl salicylate. The genital structures were examined, and pencil sketches were made under Leica MZ AP0 stereoscope (Milton Keynes, UK). The specimens were photographed using a Leica M205A stereoscopic microscope equipped with a Leica DFC425 camera and LAS software, and also some images were refined using Helicon Focus (version 5.3) software from
Helicon Soft Ltd. (Kharkov, Ukraine; www.heliconsoft. com). The images were edited in Adobe Photoshop CS4 Extended (version 11.0.2). Both images and sketches were used as templates to trace vector graphics in an Adobe Illustrator CS4 (version 14.0.0). Measurements are in millimeters. The distribution maps were created using ArcView version 9.

The specimens examined for this study are deposited in the following institutions (abbreviations and curators are given in parentheses): American Museum of Natural History (AMNH, N.I. Platnick), California Academy of Science (CAS, C. Griswold), Colección Nacional de Arácnidos/Instituto de Biología - Universidad Nacional Autónoma de México (CNAN/UNAM, O.F. Francke),
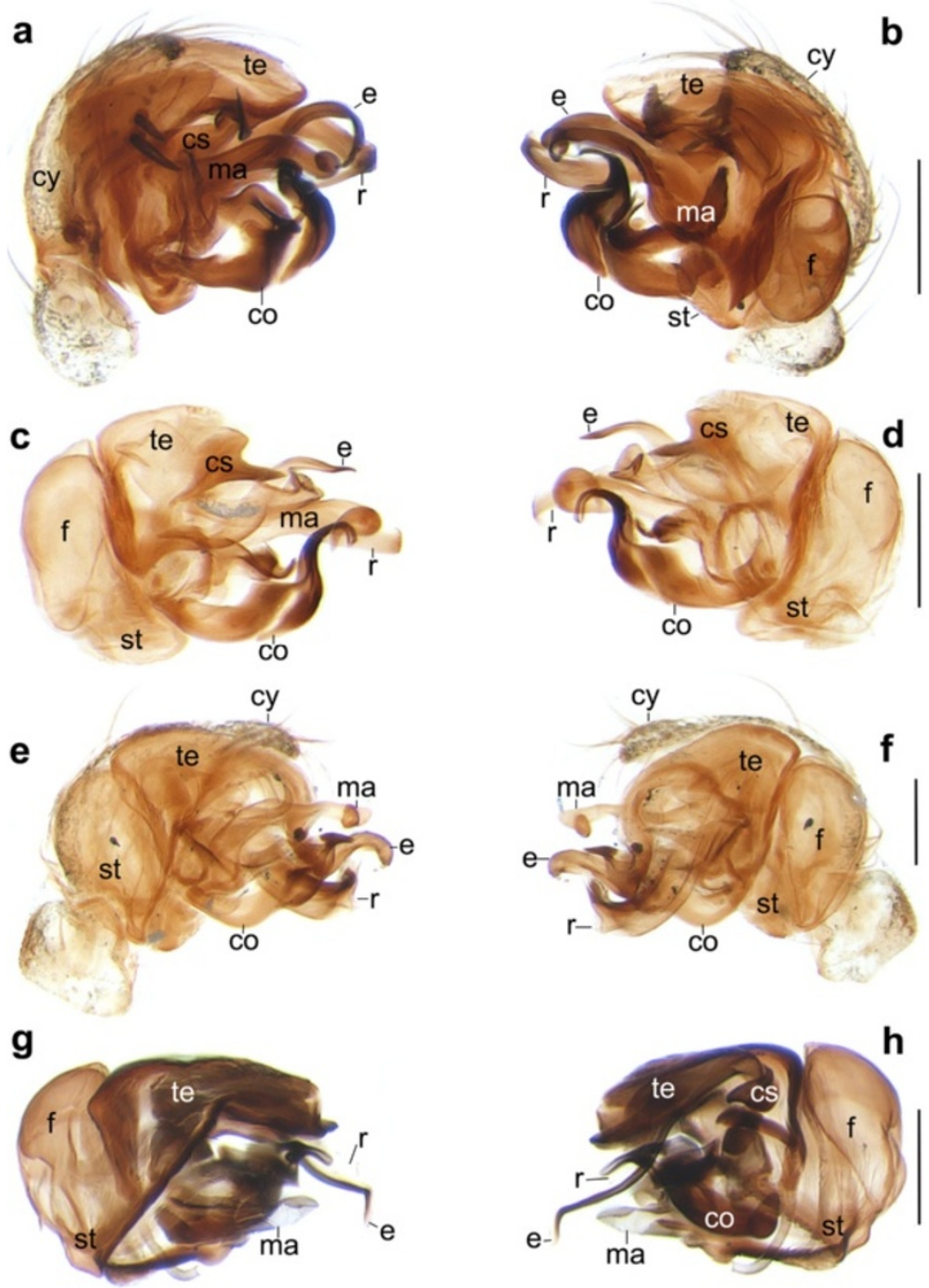

Figure 3 Palp of Ariston species, cleared. (a) Ariston albicans O. P. Cambridge, 1896, prolateral view, (b) retrolateral view; (c) Ariston aristus Opell, 1979, prolateral view, (d) retrolateral view; (e) Ariston mazolus Opell, 1979, prolateral view, (f) retrolateral view; (g) Ariston spartanus n. sp., prolateral view, (h) retrolateral view. Scale bars: (a,b,c,d,e,f,g,h) 0.1 mm. co, conductor; cs, conductor spike; cy, cymbium; e, embolus; f, fundus; ma, median apophysis; r, radix; st, subtegulum; te, tegulum. 
Instituto Nacional de Pesquisas da Amazônia (INPA, A. Henriques), and Museum of Comparative Zoology (MCZ, G. Giribet).

\section{Systematics}

Family Uloboridae Thorell, 1869

Genus Ariston O. Pickard-Cambridge, 1896

Ariston O. P.-Cambridge, 1896: 216. Type species by monotypy: A. albicans O. P.-Cambridge, 1896.

Diagnosis. Males differ from those of Siratoba by having a flat and hook-like radix (Figure 1d); heavily sclerotized, flat, and curved embolus arising anteriorly to the radix; heavily sclerotized and elongated median apophysis with a curved apex (Figures 2c,d and 1c); long and swan-neck shape conductor arising between the basis of median apophysis and radix and extends between distal portions of these sclerites; presence of a conductor spike (Figures 3a,b,c,d,e,f,g,h, 2a,b, and 1a,b; Opell (1979): pl. 3a,b; 1981: Figure one). Females possess a notch instead of a posterior hood as present in Siratoba species (Figures $4 \mathrm{c}, \mathrm{e}, \mathrm{g}, 5 \mathrm{~d}$, and 6e) and spermathecae occupying the lateral and middle area of vulva (Figures 4d,f,h, 7e, 5b,d, and 6f).

Ariston aglasices new species (Figures 5a,b, 6a,b, and 8)

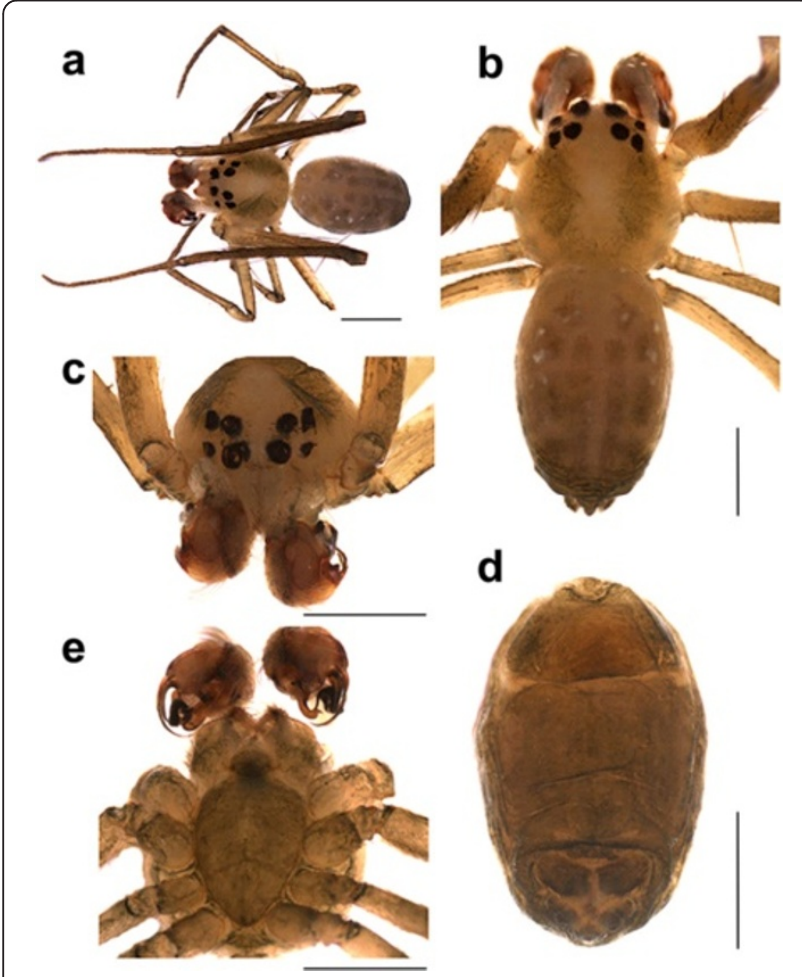

Figure 4 Ariston albicans O. P. Cambrigde, 1896, male.

(a) Habitus, (b) dorsal view, (c) carapace, anterior view,

(d) abdomen, ventral view, (e) carapace, ventral view. Scale bars: $(a, b, c, d, e) 0.5 \mathrm{~mm}$.
Type material. Female holotype from community of Bonampak (16 $\left.42^{\prime} 21.88^{\prime \prime} \mathrm{N}, 91^{\circ} 3^{\prime} 50.98^{\prime \prime} \mathrm{W}\right)$, Chiapas, Mexico, 28.x.2005, F. Álvarez-Padilha leg., deposited in MCZ.

Diagnosis. Females resemble those from $A$. spartanus n. sp. and $A$. albicans by the disposition and shape of the spermathecae, but it differs from all species of the genus by the much broader notch (Figures 5e,f and 6a,b), differs from $A$. aristus by not having distinct lobes on the posterior margin of epigynum (Figure $6 \mathrm{~b}$ ), from $A$. mazolus by the sinuous copulatory ducts (Figure 6b), and from A. spartanus n. sp. by the absence of a pit on the anterior margin of epigynum (Figure 6a).

Etymology. The epithet is masculine. Aglasices was Ariston's father and the King of Sparta between c. 575 and $550 \mathrm{BC}$.

\section{Description}

- Female (MCZ). Total length: 2.19. Carapace: 0.63 in length, 0.56 in width. Eyes: AME-AME: 0.09/ AME-ALE: 0.09/PME-PME: 0.15/PME-PLE: 0.04/ ALE-ALE: 0.36/PLE-PLE: 0.31. Abdomen: 1.56 in length, 1.0 in width. Formula for the legs: I > IV > II > III. Measurements of the legs : I: femur 1.3/patella 0.3 tibia $1.3 /$ metatarsus $1.2 /$ tarsus $0.5 /$ total 4.6 . II: 0.9/0.3/0.6/0.6/0.3/2.7. III: $0.7 / 0.2 / 0.3 / 0.4 / 0.3 / 1.9$. IV: $1.0 / 0.3 / 0.7 / 0.6 / 0.4 / 3.0$. Carapace: round and longer than wide; shallow thoracic furrow; light bluish green with dark median bands (Figure 6b). Eye tubercles with black outline; AE and PE rows slightly recurved; AME slightly larger than the other eyes; PME's tubercles elongated; PLE's tubercles slightly elongated (Figure 6b,c). Chelicerae orange. Sternum and legs dark bluish green (Figure 6d). Abdomen: oval, pale bluish green with irregular white (guanine) spots dispersed throughout the length, and lateral sides and ventral abdomen light tan (Figure 6a,b). Calamistrum present. Epigynum: epigynal field sclerotized and wider than long, with a proeminent and broad notch (Figures 5a and 6e); four spermathecae with lateral spermathecae two times the diameter of the median spermathecae (Figures $5 \mathrm{~b}$ and $6 \mathrm{f}$ ); and copulatory ducts slightly sinuous (Figure 5b).

- Male. Unknown.

Distribution. Known only from the type locality, Bonampak, Chiapas, Mexico (Figure 8).

Ariston albicans O. Pickard-Cambridge, 1896 (Figures 3a,b, 4g,h, 9a,b,c,d,e, 2a,d, 6c, and 8)

Ariston albicans O. Pickard-Cambridge, 1896: 216, pl. 27 , Figure nine (three female syntypes from Teapa, $17^{\circ} 34^{\prime}$ 

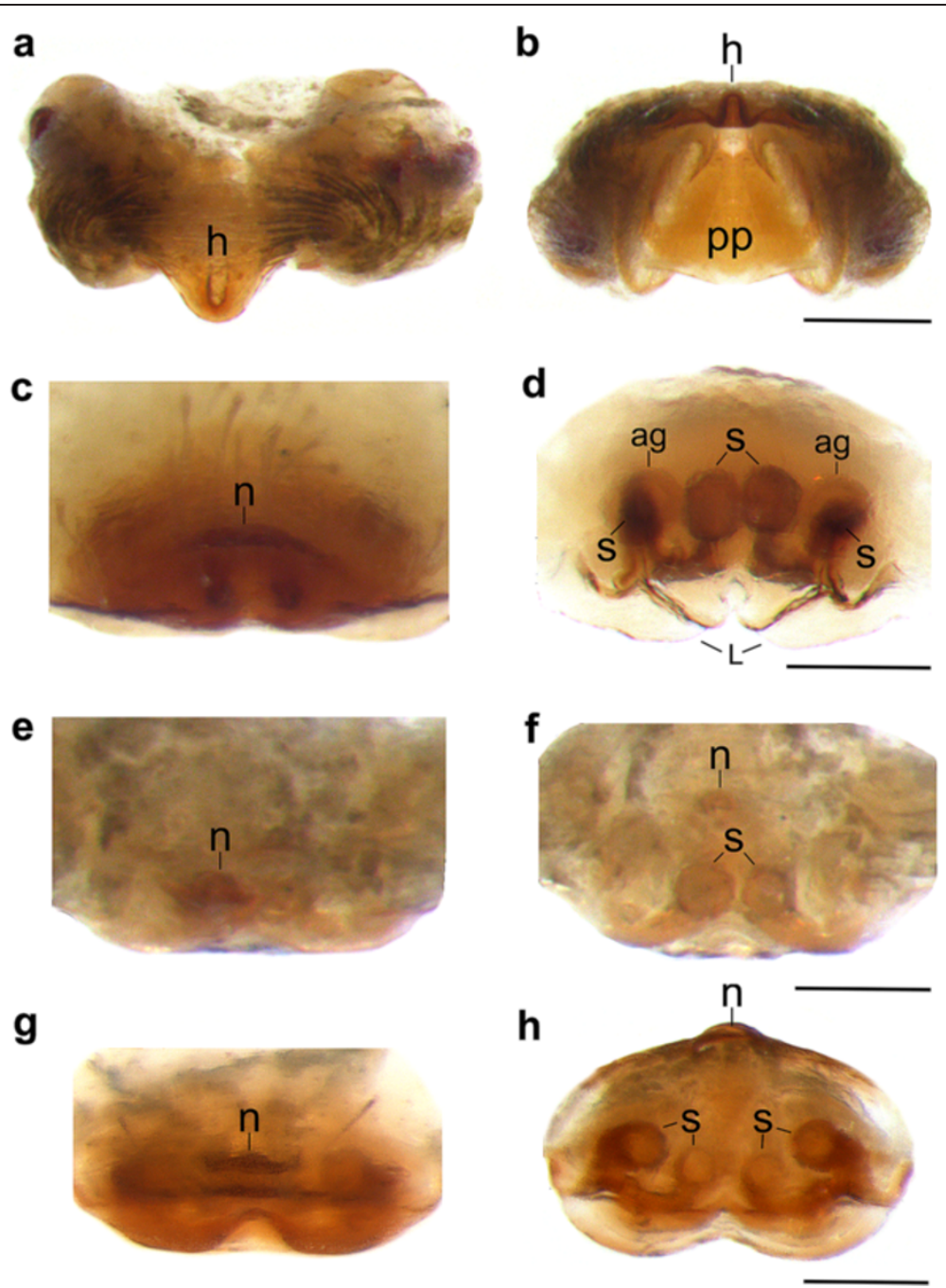

Figure 5 Epigyne of Siratoba and Ariston species. (a) Siratoba reticens (Gertsch and Davis 1942) n. comb., ventral view, (b) posterior view; (c) Ariston aristus Opell, 1979, ventral view, (d) posterior view; (e) Ariston mazolus Opell, 1979, ventral view, (f) posterior view; (g) Ariston albicans O. P. Cambrigde, 1896, ventral view, (h) posterior view. Scale bars: (a,b,c,d,e,f) $0.1 \mathrm{~mm}$. ag, accessory gland; $h$, epigynal hood; $n$, epigynal notch; $\mathrm{pp}$, posterior plate; s, spermathecae.

$1.58^{\prime \prime} \mathrm{N} 92^{\circ} 57^{\prime} 0.23^{\prime \prime} \mathrm{W}$, Tabasco, Mexico, H. H. Smith leg., deposited in BMNH, not examined); Simon (1903): 973; Kraus (1955): 79, Figures two hundred twenty-four to two hundred twenty-five; Lehtinen (1967): 463, Figures four hundred eighty-nine and four hundred ninety-two; Opell (1979): 478, Figures thirty-two to thirty-five; Platnick (2014).

Material examined Mexico, Chiapas, Reserva de La Biosfera La Encrucijada (154'5.59"N, 9245'20.02"W), 16.iv.2003, Y. Garcia leg, 38 $14{ }^{\Uparrow} 102 j$ (CNAN 2664; 2653; INPA 8801). Guatemala, El Petén Tikal, 7 to 11.x.1977, M. M. Bentzien leg, $1 ð$ (CAS).

Diagnosis. Males can be distinguished from other species of this genus by the presence of three spines on the posterolateral margin of the cymbium (Figures 3a, 2a, and 6c); they also differ from A. aristus and A. spartanus n. sp. by the embolus bended towards radix and median apophysis (Figures 3a,b and 2a,b); from A. spartanus $\mathrm{n}$. sp. by the embolus free, not lied on radix (Figures 3a,b and $2 \mathrm{a}, \mathrm{b})$; and from $A$. mazolus by the embolus and radix not bended towards and covering the conductor (Figure 3d). Females resemble those from A. spartanus n. sp. and $A$. aglasices by the disposition and shape of the spermathecae, but differs from $A$. spartanus n. sp. by the presence of notch instead of a pit and differs from $A$. aglasices by the much narrower notch (Figure 4g,h). They differ from $A$. aristus by not having a posterior margin forming two distinct lobes (Figure 4d) and from A. mazolus by the copulatory ducts sinuous (Opell (1979): Figure thirty-four). 


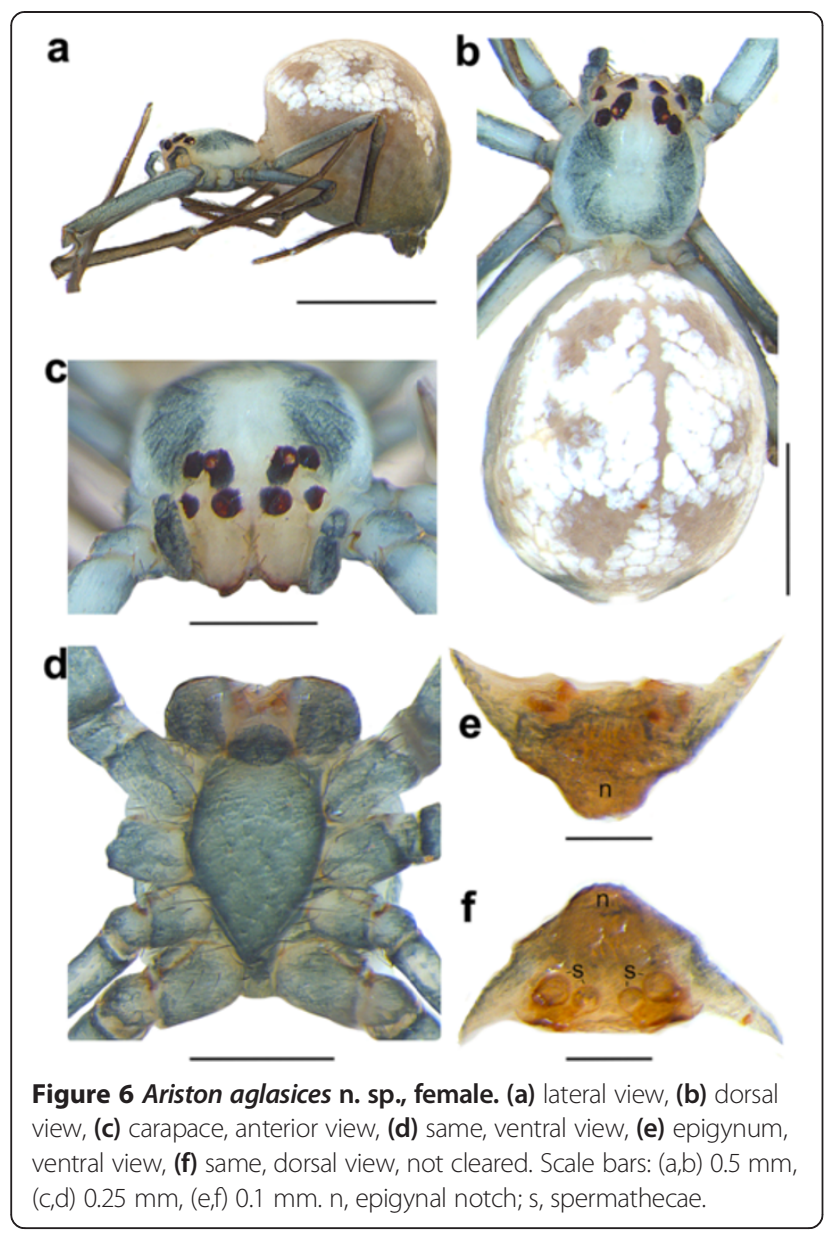

\section{Description}

- Male (INPA 8801). Total length: 2.03. Carapace: 0.78 in length, 0.72 in width. Eyes: AME-AME: 0.07/AME-ALE: 0.04/PME-PME: 0.14/PME-PLE: 0.02/ALE-ALE: 0.35/PLE-PLE: 0.35. Abdomen: 1.25 in length, 0.65 in width. Formula for the legs: I > IV > II > III. Measurements of the legs: I: femur 0.9 patella 0.2 /tibia $1.3 /$ metatarsus $1.1 /$ tarsus $0.4 /$ total 3.9. II: $0.6 / 0.2 / 0.5 / 0.5 / 0.3 / 2.1$. III: $0.5 / 0.1 / 0.3 /$ $0.3 / 0.2 / 1.4$. IV: $0.8 / 0.2 / 0.6 / 0.4 / 0.3 / 2.3$. Carapace: round and slightly longer than wide; shallow thoracic furrow; light yellow with green dark median bands (Figure 9a). Tubercles of eyes have black outline; AE and PE rows slightly recurved; AME larger than the other eyes (Figure 9b,c). Chelicerae pale yellow. Sternum, ventral abdomen, and legs pale yellow to light tan (Figure 9e,d). Abdomen: oval, tan yellow to dark green with irregular white spots dispersed throughout the length; lateral sides of the abdomen darkish. Calamistrum absent. Palpus: tibia palpal with two apical short ridges; long and curved tip radix (Figure 2a,b); conductor's tip strongly sclerotized (fig.a - b); median apophysis divided; ma1 smaller than ma2, both with curved tip, median apophysis shape as in Figure 2c,d; cymbium shape as in Figure 6c.

- Female. Described in Opell (1979): 480 to 481, Figures thirty-two to thirty-five.

Remarks. Although not examined, the illustration of the material collected in Islas de la Bahia, Honduras (one female SMF 8698, Peters Leg. 9. 1951) published by Kraus (1955) allowed the identification of this material as $A$. albicans, and it was included here in the species distribution.

Distribution. Tabasco and Chiapas (Mexico), El Petén Tikal (Guatemala), and Islas de la Bahia (Honduras) (Figure 9).

Ariston aristus Opell, 1979 (Figures 3c,d, 4c,d, 6b, 10d,e,f,g, and 9)

Ariston aristus Opell, 1979: 482, Figures forty to forty-five (female holotype, VIII.1939, A.M. Chickering leg., 20 to 24.VI., N. Banks leg, both collected from Barro Colorado Island, 99'7.57"N 7950'47.33"W, Canal Zone, Panama; and male paratype described in Opell, 1981 from the same locality as holotype; both deposited in MCZ, examined); Opell, 1981; Platnick 2014.

Diagnosis. Males can be distinguished from $A$. albicans by the lack of spines on cymbium (Figures $3 \mathrm{c}$ and $2 \mathrm{a}$ ), from $A$. mazolus and A. spartanus n. sp. by the embolus bended towards radix and median apophysis (Figure $3 \mathrm{~d}$ ), and from $A$. spartanus n. sp. by the embolus free, not lied on radix (Figures $3 \mathrm{~d}$ and 10d). Females differ from all other species of Ariston by the posterior margin of the epigynum forming two lobes with a median notch, accessory glands twice the size of the spermathecae diameter, and copulatory ducts situated transversely in relation to the posterior margin of the epigynum (Figure 4d).

Description. Female described by Opell 1979: 482, Figures forty to forty-five, and male by Opell, 1981: 219, Figures one and six.

Distribution. Canal Zone, Panama (Figure 9).

Ariston mazolus Opell, 1979 (Figures 3e,f, 4c,d, 6c, 10a,b,c, and 9)

Ariston mazolus Opell, 1979: 481, Figures thirty-six to thirty-nine, pl. 3A-B (female holotype and three male paratypes from Miramar, 19 $7^{\prime} 16.76^{\prime \prime} \mathrm{N} 104^{\circ} 22^{\prime} 18.90^{\prime \prime}$ W, Manzanillo, Colima, Mexico, F. Bonet leg, deposited in AMNH, examined); Platnick (2014).

Diagnosis. Males resemble those from A. spartanus n. sp. by the embolus bended towards radix and median apophysis, but differ by the embolus not lied on the 

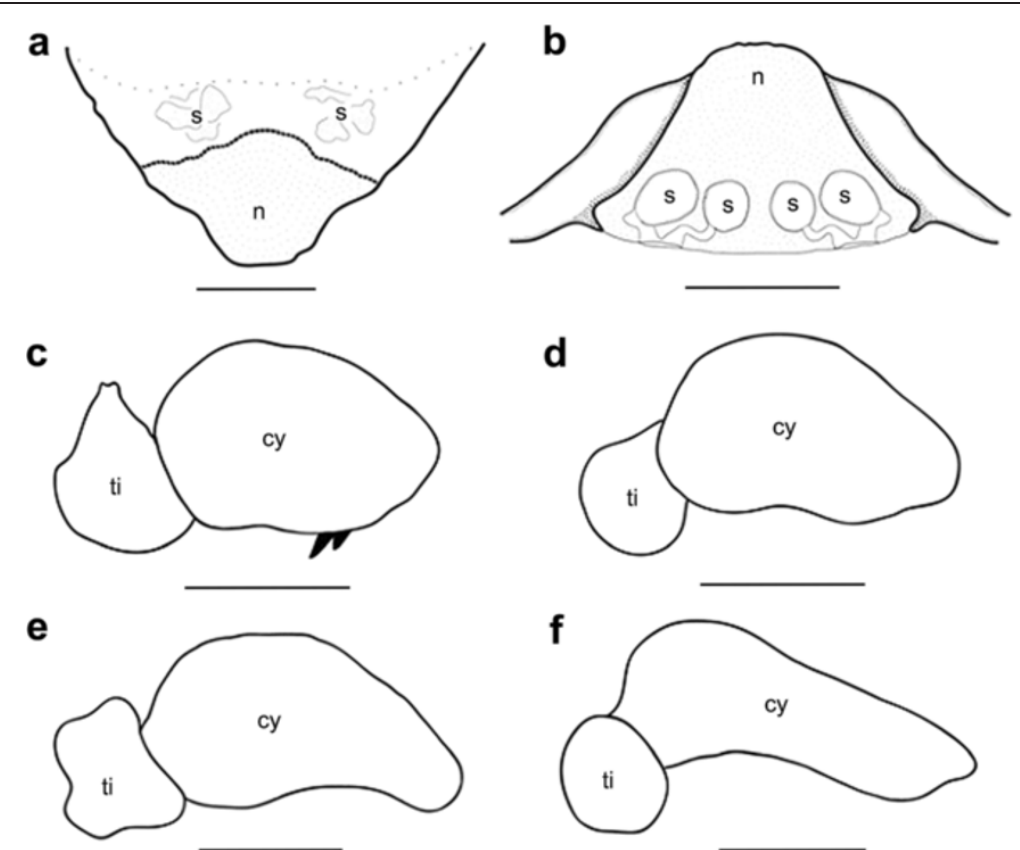

Figure 7 Ariston aglasices n. sp. epigynum, and cymbium of Ariston species. (a) Ariston aglasices n. sp., epigynum, ventral view, (b) cleared, dorsal view; (c) Ariston albicans O. P. Cambridge, 1896, cymbium, dorsal view; (d) Ariston aristus Opell, 1979, cymbium, dorsal view; (e) Ariston mazolus Opell, 1979, cymbium, dorsal view; (f) Ariston spartanus n. sp., cymbium, dorsal view. Scale bars: (a,b,c,d,e,f) 0.1 mm. cy, cymbium; n, epigynal notch; s, spermathecae; ti, tibia.

inner surface of radix (Figures $3 \mathrm{f}$ and 10a); they also differ from A. albicans by lack of spines on cymbium (Figures 3e and $6 \mathrm{c})$. Females are distinguished from all other species, externally by having the narrower notch on the anterior margin of epigynum (Figure 4e,f); they also differ from $A$. aristus by the disposition of spermathecae, the absence of lobes on posterior margin of epigynum, and by the copulatory ducts situated diagonally in relation to the posterior margin of the epigynum (Figure 4e,f); from $A$. albicans by the copulatory ducts not sinuous; and from A. spartanus n. sp. by not present a pit on the anterior margin of epigynum (Figure 4e,f).

Description. Male and female described in Opell (1979):481, Figures thirty-six to thirty-nine, pl. 3A-B.

Distribution. Colima (Mexico) (Figure 9).

Ariston spartanus new species (Figures 3g,h, 7a,b,c,d,e, 11a,b,c,d,e,f,g, 1a,b,c,d,e,f, 6f, and 9)

Type material. Male holoype from community of

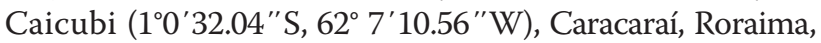
Brazil, visual nocturnal search, 25.x.2008, A.L. Tourinho leg., deposited in INPA 8800.

Diagnosis. Males resemble those from A. mazolus by the embolus bended towards radix and median apophysis, but differ from this and all other species by the embolus lied on the inner surface of radix (Figure 1d); they also differ from A. albicans by lacking spines on the posterolateral margin of the cymbium (Figures $3 \mathrm{c}$ and 10d). Females can be readily recognized by the presence of a furrow; all other Ariston species present a notch (Figures 11e and 1e).

Etymology. The epithet is masculine, and Latin for Sparta was chosen here in reference to the historical name of the genus who was the Greek king 'Apiot $\omega v$ (Ariston), the King of Sparta during the Battle of the Fetters, between c. 550 and 515 BC.

\section{Description}

- Male (INPA 8800). Total length: 1.55. Carapace: 0.60 in length, 0.61 in width. Eyes: AME-AME: 0.09/ AME-ALE: 0.04/PME-PME: 0.14/PME-PLE: 0.06/ ALE-ALE: 0.32/PLE-PLE: 0.32. Abdomen: 0.95 in length, 0.62 in width. Formula for the legs: I > II > IV > III. Measurements for the legs: I: femur 0.9/ patella $0.2 /$ tibia $1.0 /$ metatarsus $0.9 /$ tarsus 0.4 /total 3.4. II: 0.7/0.2/0.6/0.6/0.3/2.4. III: 0.6/0.1/0.3/0.4/0.2/ 1.6. IV: $0.7 / 0.2 / 0.5 / 0.5 / 0.3 / 2.2$. Carapace: round and slightly wider than long; shallow thoracic furrow; light green from clypeus to median area and dark green median bands (Figure $7 \mathrm{~b}, \mathrm{c}$ ). Eyes tubercles outline black; PE's tubercles slightly elongated; $\mathrm{AE}$ rows slightly procurved; PE rows recurved; AME twice the size of the other eyes (Figure 7b,c). Eye area with several black thick setae. Chelicerae light green. Sternum and ventral abdomen green (Figure $7 \mathrm{~d}, \mathrm{e}$ ). Legs green with orange shades (Figure 7a). Abdomen 


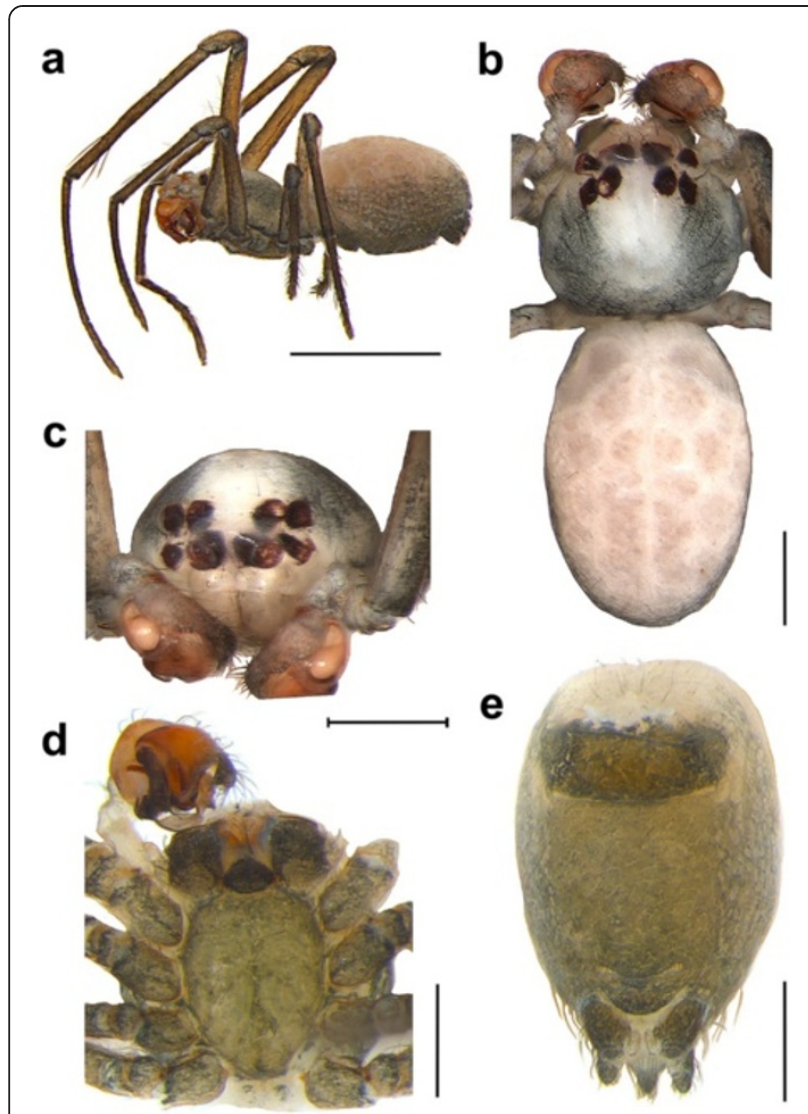

Figure 8 Ariston spartanus $\mathbf{n}$. sp., male. (a) Lateral view, (b) dorsal view, (c) carapace, anterior view, (d) carapace, ventral view, (e) abdomen, ventral view. Scale bars: $(a, b) 0.5 \mathrm{~mm}$, $(c, d, e) 0.25 \mathrm{~mm}$.

oval, pale white with lateral sides of the abdomen dark to light green (Figure 7a,b). Calamistrum absent. Prolateral row of trichobothria on femur II to V. Palpus: tibia palpal without apical ridges, long and curved tip radix (Figure 1b,d); conductor's tip strongly sclerotized (Figure 1a,b); median apophysis divided; ma1 smaller than ma2, both with curved tip, median apophysis shape as in Figure 1c; cymbium shape as in Figure $6 \mathrm{f}$.

- Female (INPA 8880). Total length: 1.89. Carapace: 0.64 in length, 0.61 in width. Eyes: AME-AME: 0.08/ AME-ALE: 0.03/PME-PME: 0.12/PME-PLE: 0.06/ ALE-ALE: 0.30/PLE-PLE: 0.29. Abdomen: 1.25 in length, 1.10 in width. Formula for the legs: I > II > IV $>$ III. Measurements for the legs: I: femur 1.3/ patella $0.3 /$ tibia $1.1 /$ metatarsus $1.0 /$ tarsus $0.4 /$ total 4.1. II: $0.8 / 0.2 / 0.5 / 0.5 / 0.3 / 2.3$. III: $0.5 / 0.2 / 0.3 / 0.4 /$ 0.3/1.7. IV: 0.6/0.2/0.6/0.5/0.3/2.2. Carapace: round and slightly longer than wide; shallow thoracic furrow; light green from clypeus to median area, and dark green median bands (Figure 11a,b). Eye tubercles have black outline; PE's tubercles slightly elongated; AE and PE rows recurved; AME larger than the other eyes (Figure 11b,d). Chelicerae light green. Sternum, ventral abdomen, and legs green (Figure $11 \mathrm{c}, \mathrm{f}$ ). Abdomen: oval, light white to light brown with irregular white (guanine) spots dispersed throughout the length; lateral sides of the abdomen dark to light green (Figure 11a,b). Calamistrum present. Prolateral row of trichobothria on femur II to V. Epigynum: epigynal field sclerotized and wider than long, has four spermathecae with equal sizes, and copulatory ducts not sinuous (Figures 11e,g and 1e,f).

Distribution. Known only from the type locality, Caicubi, Roraima, Brazil (Figure 9).

\section{Genus Siratoba Opell, 1979}

Siratoba Opell, 1979: 486. Type species by original designation: A. referens Muma \& Gertsch, 1964.

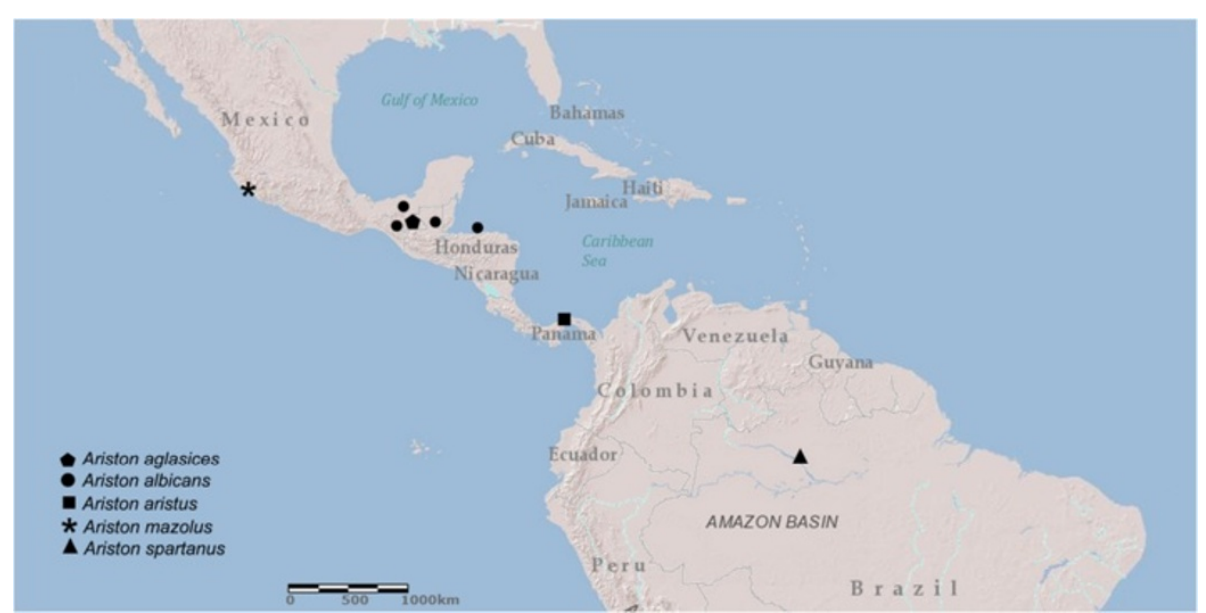

Figure 9 Distribution map of Ariston species. 

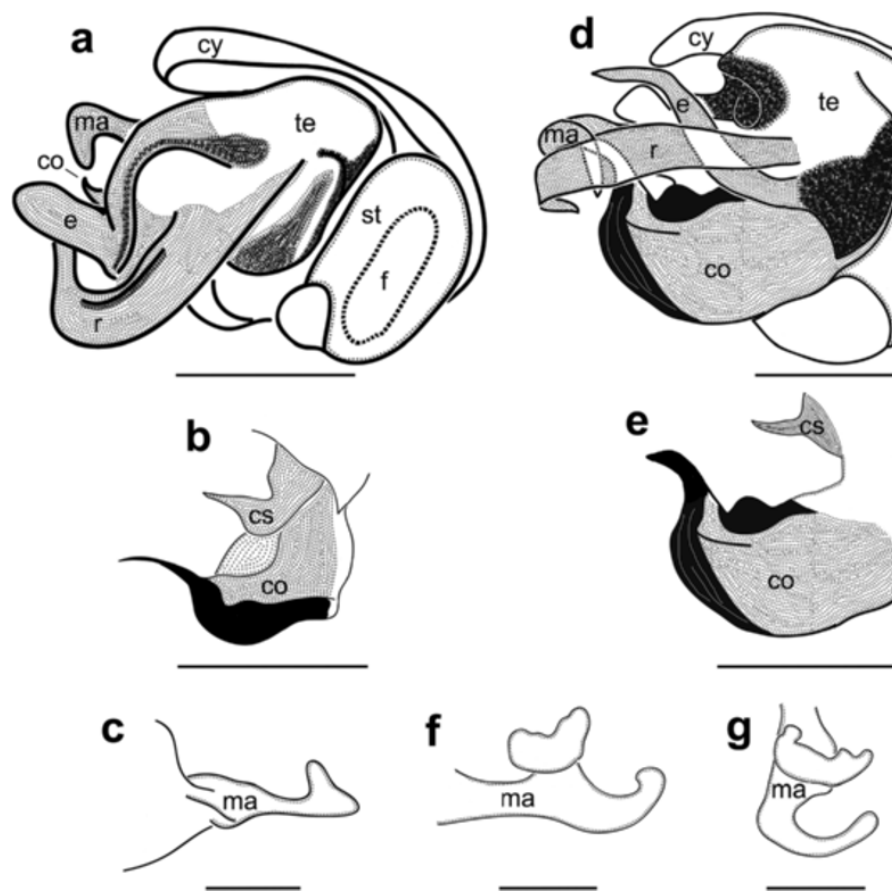

Figure 10 Palp of Ariston mazolus Opell, 1979 and Ariston aristus Opell, 1979. Ariston mazolus Opell, 1979 (a) retrolateral, (b) conductor and conductor spike, retrolateral view, (c) median aphophysis, prolateral view. Ariston aristus Opell, 1979 (d) retrolateral view, (e) conductor and conductor spike, retrolateral view, (f) median aphophysis, retrolateral view, (g) same, apical view. Scale bars: (a,b,d,e) 0.1 mm, (c,f,g) 0.05 mm. co, conductor; cs, conductor spike; cy, cymbium; e, embolus; f, fundus; ma, median apophysis; r, radix; st, subtegulum; te, tegulum.

Diagnosis. Males differ from Ariston by the coiled radix with a central groove in which the thin and curved embolus lies, u-shaped conductor, and small and not projected median apophysis (Figures 12a,b,c,d,e,f; Gertsch and Davis (1942), Figure forty-three; Opell (1979): pl. 3c-d, Figure sixty-eight to sixty-nine; Coddington (1990): Figure forty-two; Roth (1982): Figure three; Roth (1985): Figure three; Roth (1994), Figure three). Females differ from those of Ariston by the presence of a heavily sclerotized posterior plate and the presence of a prominent ventral hood instead of a notch as present on Ariston species; spermathecae occupying only the lateral area of vulva (Figure 4a,b; Muma and Gertsch (1964): Figure thirty-seven; Opell (1979): Figures sixty-five to sixty-seven and seventy-five to seventy-seven; Roth (1982): Figure two; Roth (1985): Figure two; Roth (1994), Figure two).

Siratoba referens (Muma and Gertsch 1964; Figures 12a, b,e, 13a,f,g,h, and 14)

Ariston referens Muma and Gertsch, 1964: 17, Figures thirty-six to thirty-nine (male holotype and female paratype from Cochise Stronghold, 31 $56^{\prime} 22.30^{\prime \prime} \mathrm{N} \mathrm{109} 58^{\prime}$ 55.25"W, Dragoon Mountains, Arizona, W. J. Gertsch leg., deposited in the AMNH, male examined, female not examined).
Siratoba referens: Opell (1979): 488, Figures sixty-five to seventy-four, pl. 3C-D (n. comb.); Roth (1982): 50 to 1, Figures two to three; Roth (1985), B46-3, Figures two to three; Roth (1994): 192, Figures two to three; Coddington (1990), Figure forty-two; Platnick (2014).

Diagnosis. Males differ from those of $S$. reticens by the radix forming a short curl, embolus, and radix of same size, and the dorsal margin of radix not indented (Figure 12a,b,e; Muma and Davis (1964), Figure thirty-seven). Females differ from those of $S$. reticens by the broad hood and the lack of a pit on its tip on the anterior margin of epigynum (Opell (1979): Figure sixty-five), posterior plate's margin concave (Opell (1979): Figures sixty-five to sixty-seven), and coiled copulatory duct in a parallel position in relation to the posterior margin of epigynum (Opell (1979): Figure sixty-seven).

Description. Male and female described by Muma and Gertsch (1964): 17, Figures thirty-six to thirty-nine and redescribed in Opell (1979): 488, Figures seventy-five to seventy-seven.

Distribution. Dragoon Mountains, AZ, USA (Figure 14).

Siratoba reticens (Gertsch and Davis 1942) new combination (Figures 4a,b, 12c,d,f, 13b,c,d,e, and 14)

Ariston reticens Gertsch and Davis, 1942: 17, Figure forty-three (male holotype and two immature paratypes 


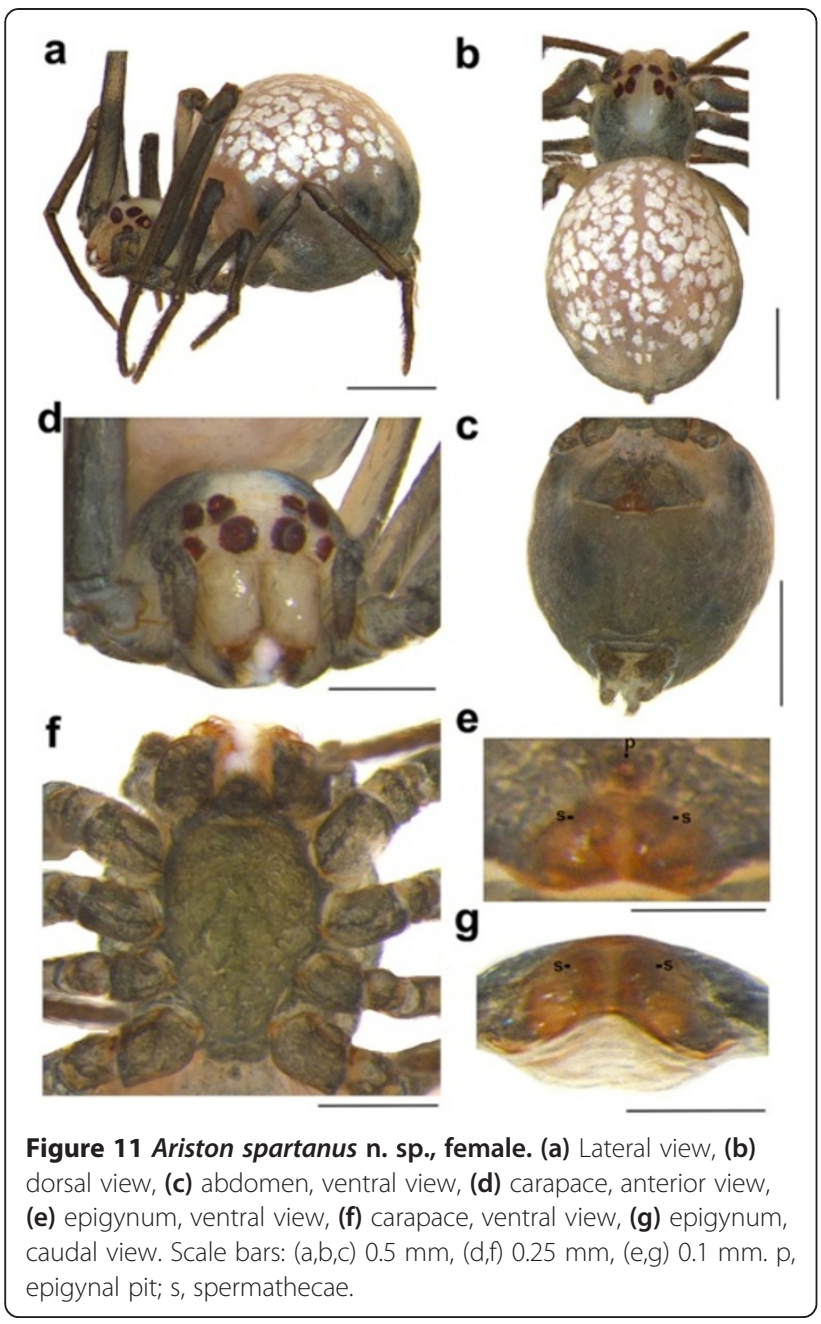

from 23 miles east of Ciudad del Maiz, 22 $23^{\circ} 59.46^{\prime \prime} \mathrm{N}$ 99 36'10.59"W, San Luis Potosi, Mexico, A.M. Davis leg., deposited in AMNH, examined). Roewer (1955): 1335; Platnick (2014).

Siratoba sira Opell, 1979; Platnick, 2014 (female holotype from entrance of cave Taninuí, 21 $57^{\circ} 24.58^{\prime \prime}$ N 98 53'19.23"W, San Luis Potosi, Mexico, 29.III. 1940, W. Bridge leg., deposited in AMNH, examined); Platnick (2014). New synonym

Diagnosis. Males differ from $S$. referens by the radix forming a long curl, the embolus shorter than the radix, and the dorsal margin of radix indented (Figure 12c,d,f; Gertsch and Davis (1942): Figure forty-three). Females differ from those of S. referens (Opell (1979): Figures sixty-five to sixty-seven) by the narrower hood and presence of a pit on its tip (Figure 4a), posterior plate's margin convex (Opell (1979): Figures seventy-five to seventy-six), and coiled copulatory duct in a transverse position in relation to the posterior margin of epigynum (Opell (1979): Figure seventy-seven).

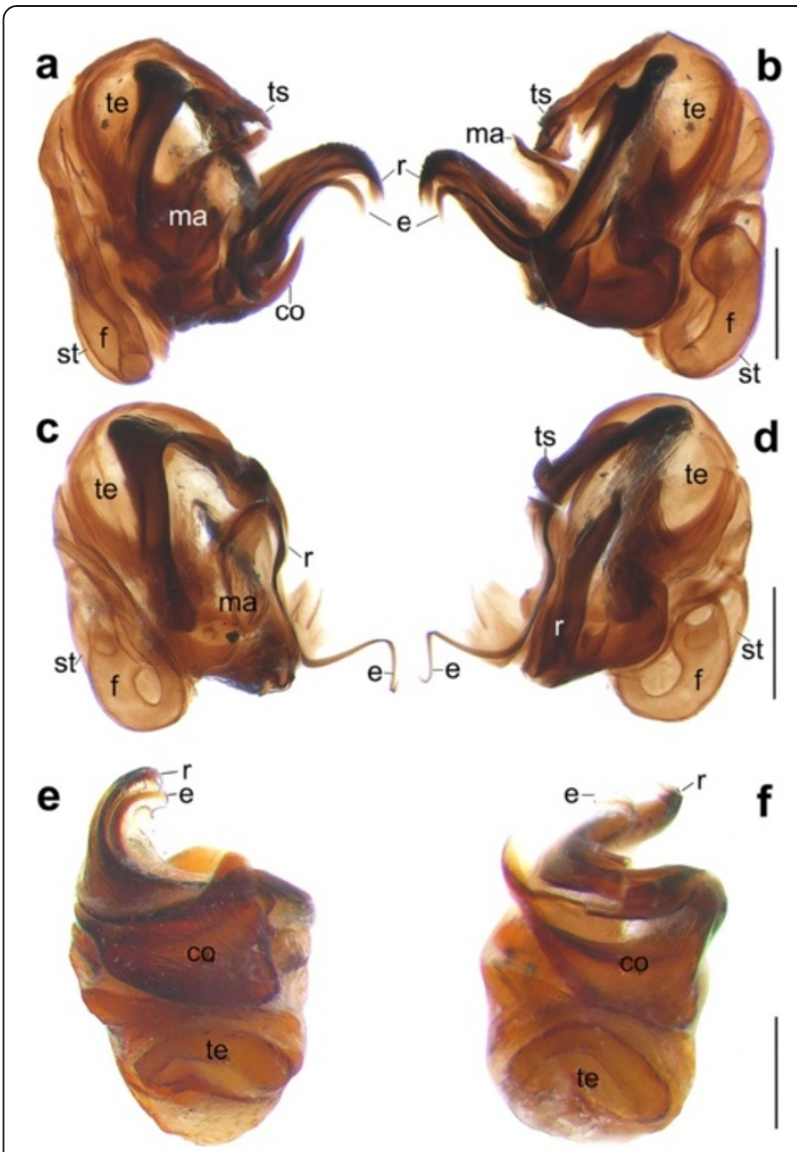

Figure 12 Palp of Siratoba species. (a) Siratoba referens (Muma and Gertsch 1964), retrolateral view, (b) prolateral view; (c) Siratoba reticens (Gertsch and Davis 1942) n. comb., retrolateral view, (d) prolateral view; (e) Siratoba referens (Muma and Gertsch 1964), posterior view; (f) Siratoba reticens (Gertsch and Davis 1942) n. comb., posterior view. Scale bars: $(a, b, c, d, e) 0.2 \mathrm{~mm}$. co, conductor; e, embolus; f, fundus; ma, median apophysis; r, radix; te, tegulum; ts, tegular spur.

Remarks. Both Ariston reticens and Siratoba sira were described based on one sex. Having examined the holotypes of both nominal species and being the proximity of the locality types, we were unable to find differences justifying their separation, which has led us to consider the examined specimens to be conspecific. Therefore, we synonymized Siratoba sira under Ariston reticens.

Description. Male described by Gertsch and Davis (1942): 17, f. 43, and female described by Opell (1979): 490, f. 75 to 77 .

Distribution. San Luis Potosi (Mexico) (Figure 14).

\section{Results and discussion}

The diagnosis presented here is a combination of the characters of palpus and epigynum described by Opell (1979) and new diagnostic characters found in the course of this study. The diagnostic characters recovered 

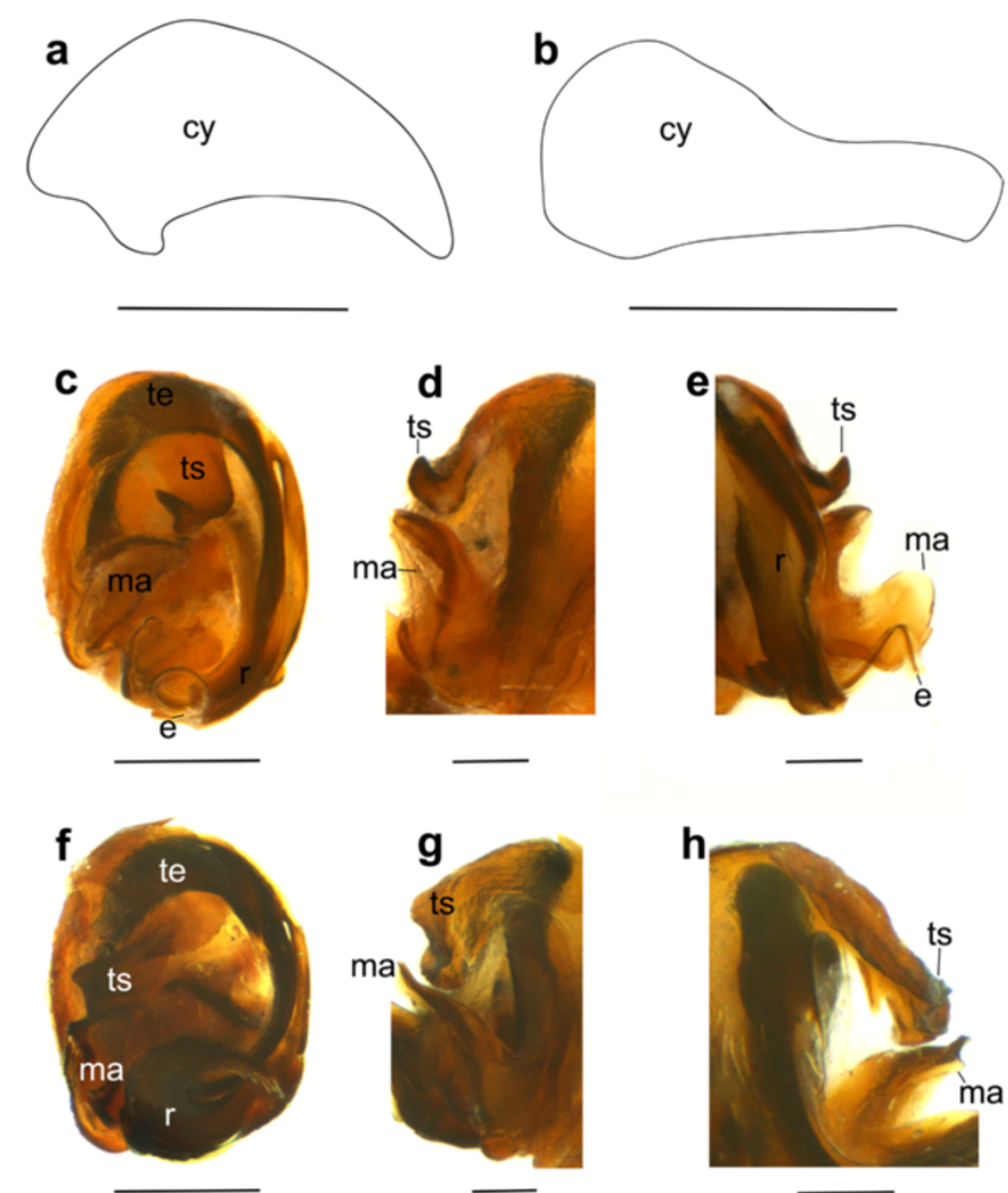

Figure 13 Cymbium and palp sclerites of Siratoba species. (a) Siratoba referens (Muma and Gertsch 1964), cymbium, dorsal view; (b) Siratoba reticens (Gertsch and Davis 1942) n. comb., cymbium, dorsal view; (c) Siratoba reticens (Gertsch and Davis 1942) n. comb., palpus, anterior view, (d) details of the tegular spur and median apophysis, prolateral view, (e) same, retrolateral view; (f) Siratoba referens (Muma and Gertsch 1964), palpus, anterior view, (g) details of the tegular spur and median apophysis, prolateral view, (h) same, retrolateral view. Scale bars: (a,b) $0.3 \mathrm{~mm}$, (c,f) $0.2 \mathrm{~mm}$, (d,e) $0.5 \mathrm{~mm}$, (g) $0.1 \mathrm{~mm}$, (h) $0.2 \mathrm{~mm}$. cy, cymbium; e, embolus; ma, median apophysis; r, radix; te, tegulum; ts, tegular spur.

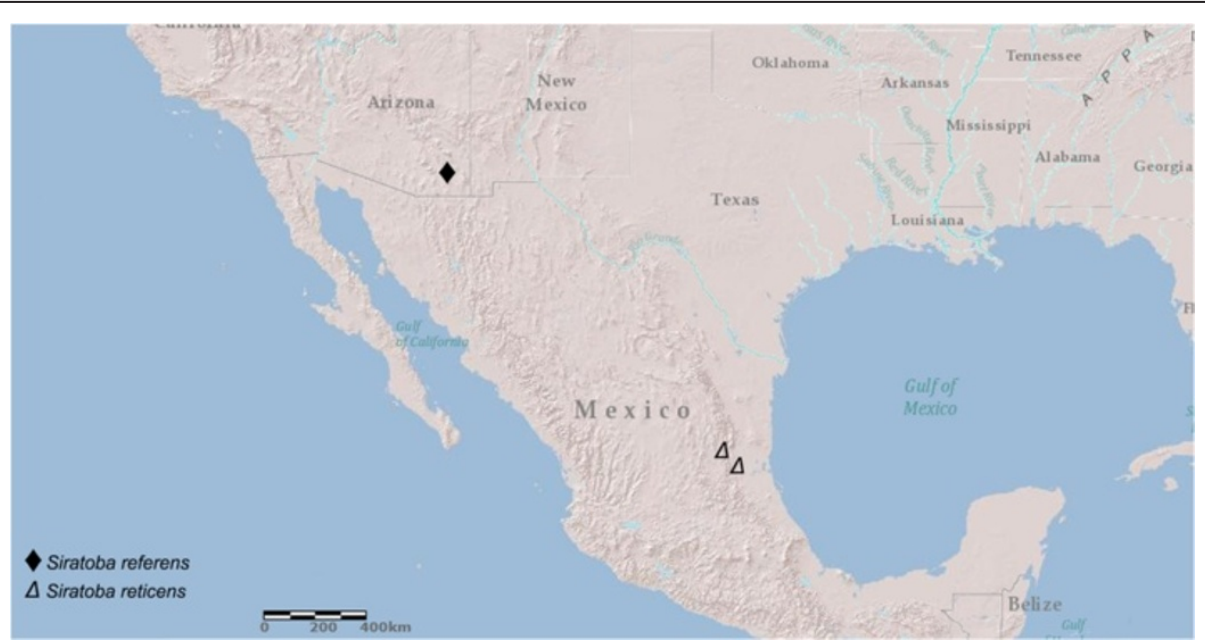

Figure 14 Distribution map of Siratoba species. 
from Opell's revision (1979) were as follows: (1) the shape of radix, (2) the shape and orientation of embolus, (3) the shape of median apophysis, and (4) presence of the posterior hood. The new diagnostic characters added were the following: (1) the shape and orientation of conductor, (2) presence and shape of the conductor spike, (3) disposition of the spermathecae, (4) shape of cymbium, (5) presence of spines on cymbium, (6) orientation of the embolus, (7) shape of the copulatory ducts, and (8) presence of notch or pit on epigynum.

The total body length, ratios between carapace width and length and between first femur length and carapace length, the distances between the eyes and height of the clypeus, and distribution ranges were removed in this revised diagnosis because they are not sufficiently clear to distinguish neither genera nor species. For most species, the only material available to study were the type material, so the SEM photos could not be provided, and since the material is already too fragile, the genitalia were cleared only with clove oil.

The accessory glands described by Opell (1979) for almost all species of Ariston and Siratoba and the exact localization of the fertilization ducts could not be clearly visualized in most species; thus, those two characters were not described and used here. However, for A. aristus, the accessory glands could be easily seen, and it was used as diagnostic character for this species.

On the epigynum external morphology, a clear differentiation of epigynal notch, present in Ariston species, and epigynal hood, present in Siratoba species, is provided here: the first is a notch (that could be presented as a pit as in A. spartanus n. sp.) on the anterior portion of the epigynal area that is not prominent enough to overlay the epigynal area in ventral view and is not associated with a posterior plate, and a epigynal hood is in the same portion of the epigynal areas as in the notch but is prominent enough to overlay the epigynal area and the posterior plate is present.

On males, the conductor spike was identified in Ariston species, and tegular spur in Siratoba species. The conductor spike, also present in Philoponella species (Opell, 1979), is described here as a weakly (as in A. aristus and A. mazolus) to heavily sclerotized spike (as in $A$. albicans and $A$. spartanus n. sp.) arising above the conductor with variable shapes among the species. And the tegular spur is present in Zosis, Octonoba, and Purumitra (Opell 1979) arising from the lateral tegular surface; in Siratoba, it arises from the apical portion of the tegulum.

The distal portion of the palpus to the median apophysis is less pleated and is slightly sclerotized, so we considered subtegulum the more distal and less sclerotized portion that bears the fundus, and tegulum the more apical and sclerotized portion. In Opell's revision (1979), he identified tegulum as the distal surface which arises from the median apophysis, and the remaining area of the distal portion were left unnamed. Here, no visible differentiation that would let the area of hematodocha be identified more clearly was found. In Ariston species, the median apophysis is present and can be an elongated projection without prongs (A. mazolus), with one prong (A. albicans and $A$. aristus), or three prongs (A. spartanus n. sp.).

\section{Conclusions}

In total, five species are recognized in Ariston, including two new species, and two species are recognized in Siratoba. New diagnostic characters are suggested for defining the genera and their species. Unfortunately, data about natural history of those species remains unknown.

\section{Abbreviations}

AE: anterior eyes; AME: anterior median eyes; PE: posterior eyes; PME: posterior median eyes; ag: accessory gland; co: conductor; cs: conductor spike; cy: cymbium; e: embolus; f: fundus; h: epigynal hood; I: epigynal lobe; ma: median apophysis; n: epigynal notch; p: epigynal pit; pp: posterior plate; r: radix; s: spermathecae; st: subtegulum; te: tegulum; ti: tibia; ts: tegular spur.

\section{Competing interests}

The authors declare that they have no competing interests.

\section{Authors' contributions}

LS was responsible for species description, examination of the materials, and in drafting the manuscript. ALT and ADB drafted the manuscript and revised it critically for important intellectual content. All authors read and approved the final manuscript.

\section{Acknowledgements}

We thank the curators for the loan of the material. To the Jufari Expedition team Cristina Rheims, Gonzalo Giribet, Gustavo Hormiga, Jesus Ballesteros, Ligia Benavides, Osmaildo F. da Silva, Thiago da S. Moreira, Rafael Indicatti and Willians Porto and the crew of Vitória Amazônica Foundation. The first author thanks Charles Griswold for providing an internal grant to visit the California Academy of Science (CAS). The Coordination of Improvement of Higher Education Personnel-CAPES (grant PNPD\#03017/09-5 to ALT) and the Brazilian National Council for Scientific and Technological Development-CNPq through the Brazilian Research Program for Biodiversity-PPBio for Ph.D. fellowship to LSPT (CSF\# 200494/2013-9) and by a CNPq (Proc. 301776/2004-0) to A.D. Brescovit.

\section{Author details}

${ }^{1}$ Coordenação de Biodiversidade, Instituto Nacional de Pesquisas da Amazônia (INPA), Avenida André Araújo, 2936, Aleixo, Cx. Postal 478, Manaus, AM 69011-970, Brasil. '2Department of Biological Sciences, The George Washington University, Washington D.C. 20052, USA. ${ }^{3}$ Museum of Comparative Zoology, Department of Organismic and Evolutionary Biology, Harvard University, 26 Oxford Street, Cambridge, MA 02138, USA. ${ }^{4}$ Laboratório Especial de Coleções Zoológicas, Instituto Butantan, Av. Vital Brasil, 1500, São Paulo 05530-900, Brasil.

Received: 16 February 2014 Accepted: 19 May 2014 Published online: 28 June 2014

\section{References}

Coddington JA (1990) Ontogeny and homology in the male palpus of orb-weaving spiders and their relatives, with comments on phylogeny (Araneoclada: Araneoidea, Deinopoidea). Smithson Contrib Zool 496:1-52, http://dx.doi.org/10.5479/si.00810282.496

Gertsch WJ, Davis LI (1942) Report on a collection of spiders from Mexico. IV. Am Mus Novit 1158:1-19

Kraus O (1955) Spinnen aus El Salvador (Arachnoidea, Araneae). Abh Senckenb Naturforsch Ges 493:1-112 
Lehtinen PT (1967) Classification of the cribellate spiders and some allied families, with notes on the evolution of the suborder Araneomorpha. Ann Zool Fenn 4:199-468

Muma MH, Gertsch WJ (1964) The spider family Uloboridae in North America north of Mexico. Am Mus Novit 2196:1-43

Opell BD (1979) Revision of the genera and tropical American species of the spider family Uloboridae. Bull Mus Comp Zool Harvard Univ 148:443-549

Pickard-Cambridge O (1896) Arachnida. Araneida. In: Biologia Centrali-Americana, Zoology, vol 1. London, pp 161-224

Platnick NI (2014) The world spider catalog, version 12.5. American Museum of Natural History, New York, http://research.amnh.org/iz/spiders/catalog/ ULOBORIDAE.html. Accessed 12 Feb 2014

Roewer CF (1955) Katalog der Araneae von 1758 bis 1940, bzw. 1954, vol 2. Kommissions-Verlag von "Natura", Bruxelles, pp 1-1751

Roth VD (1982) Handbook for Spider Identification. Roth, Portal

Roth VD (1985) Spider genera of North America. American Arachnological Society, Gainesville

Roth VD (1994) Spider genera of North America, with keys to families and genera, and a guide to literature, 3rd edn. American Arachnological Society, Gainesville, p 203

Simon E (1903) Histoire Naturelle des Araignées, 2nd edn. Roret, Paris, pp 669-1080

doi:10.1186/s40555-014-0028-0

Cite this article as: Salvatierra et al:: Revision of the spider genera Ariston O. P.-Cambridge, 1896 and Siratoba Opell, 1979 (Arachnida: Araneae: Uloboridae) with description of two new species. Zoological Studies 2014 53:28

\section{Submit your manuscript to a SpringerOpen ${ }^{\circ}$ journal and benefit from:}

- Convenient online submission

- Rigorous peer review

- Immediate publication on acceptance

- Open access: articles freely available online

- High visibility within the field

- Retaining the copyright to your article 